Journal Of Agriculture and Social Research (JASR) Vol. 8, No.1, 2008

\title{
EFFECTIVENESS OF FOREIGN DIRECT INVESTMENT POLICY IN NIGERIA (1986-2005)
}

\section{STEVE.O. TAMUNO AND FELIX JEBBIN MACLEAN}

\begin{abstract}
The paper dwells on an investigation of the effectiveness of foreign direct investment policy in Nigeria. Employing the ordinary least square regression technique, the null hypothesis of no significant relationship between foreign direct investment policy measures and foreign direct investment was tested. The null hypothesis was rejected and the alternative hypothesis accepted, meaning there is a significant relationship between foreign direct investment policy measures and the inflow of foreign direct investment. The coefficients of the explanatory variables are statistically significant and there is a positive relationship between foreign direct investment and liberalization and capital repatriation. The null hypothesis was tested using $f$-ratio and the student t- test was used to test the statistical significance of the policy variables at 95. Percent significant level.
\end{abstract}

Key words: foreign direct investment (FDI) policy, Nigeria

\section{INTRODUCTION:}

Output and employment are generated by investment. Gross investment, $\left(\mathrm{i}^{\mathrm{g}}\right)$ is the sum of net investment, (in) and replacement investment $\left(\mathrm{i}^{\mathrm{s}}\right)$. The evidence all around in Nigeria is that replacement investment has not been met in many sectors-service sector [roads, power plants and transport (rail line and airway rolling stocks)], in the manufacturing sector (1000 capacity utilization, closed plants, and warehouse turned to workshop centres), agriculture (decline in export of product) and mine (reduced output of columbite, bitumen and even crude oil) (Ukeje, 2003). Many reasons have been adduced to explain this ugly scenario-prominent among them are: inadequate savings and high interest rate in the economy. Obadan and Odusola (2001) argued that "domestic savings in many developing countries were barely sufficient to maintain existing capital stock, and hence could not permit enough investment to sustain economic growth. With regard to interest rate Mankiw (1997) states that "the higher the interest rate, the fewer investment projects are profitable", hence a fall in investment rate.

To ameliorate the problem of inadequate savings, government has adopted several foreign investment policies to attract foreign direct investment, because it is seen as a way of introducing external savings into the domestic economy and help in the economic growth of the country. But the pertinent question to ask is: how effective are these policies in attracting foreign direct investment into the country?. Our study, therefore, seek to examine the effectiveness of foreign direct investment policy in attracting foreign direct investment into Nigeria.

\section{Theoretical frame work/literature Review}

The eclectic theory which forms the theoretical framework of this study is attributed to Dunning (1981). The elective theory of foreign direct investment often referred to as the OLI paradigm, attempts to integrate these explanations.

The O,L, and I in the paradigm refer to the three groups of conditions that determine whether a firm, industry or company will be a source or a host of foreign direct investment. These groups have ownership advantages, considerations and internalization gains. According to this theory ownership advantages, locational-specific advantage and internalization gains determine the inflow of foreign direct investment into a country. Location specific advantage must derive from the macroeconomic environment as well as from country endowments. These specific endowments 
include national resources, markets, labour, government policies etc. necessary for foreign investment.

According to Central Bank of Nigeria (1997), netflow of foreign investment into a country is considered as an indicator of a macroeconomic stability.

Fernandez- Aria and Martiel (1996), argued that foreign direct investment is more sensitive to domestic factors than the more liquid portfolio flows, which are not so prominent in the capital flow component in Nigeria.

Empirical studies of foreign capital flows to developing countries indicate that changes in output are the most important determinants of private capital inflow. This view is shared by Green and Villain Vera (1991). Incentives such as government policies on tax, infrastructural development etc, can induce the flow of private capital investment. Shaikh (1999), listed factors that serve as strong influences on foreign capital flows which include: abolition or reduction of credit controls, allowance of market forces to determine exchange rate, deregulation of interest rates, allowance of free entry into the banking industry and generally into the financial services industry, increased autonomy of supervising agents, and reduction in direct interference by government and removal of regulatory restrictions to allow the free flow of capital into and out of the country for investment purposes.

Policies that ensure general macro-economic stability, integrate markets and open sectors to private enterprise can help to expand the range of profitable investment (Aremu, 2003). Policies that specifically reduce regulatory barriers facing investors and ensure the repatriation of capital and income are in turn necessary to translate potential for profit into viable investment projects. Many countries have adopted the normal marketing techniques to affect investment.

Preferment and madarassy (1992) outlined the following as some of the determinants of foreign direct investment: the size of the domestic market of the recipient country; the capacity utilizations of existing plants; the level of fiscal deficits; the price level or inflation rate; exchange rate volatility; the general level of interest rates; and macroeconomic policies and institutional factors. According to them where the size of the domestic market is considerably large, there will be opportunity for increased demand to spur rapid investment. Low fiscal deficits, stable prices and exchange rate will provide opportunity for decline in the cost of capital goods, which will spur replacement investment.

\section{Policy measures adopted to attract foreign Direct investment in Nigeria.}

In order to attract foreign investors into the country several policy measures have been adopted by the government. The government in 1986 under the structural adjustment programme (SAP) adopted the flotation exchange rate policy. In view of this the Foreign Exchange Monitoring and Miscellaneous Provisions) FEMAMP Act was enacted in 1995. It was enacted to liberalize transactions involving foreign exchange and thereby commands a freer flow of foreign direct investment. Investment incentives (tax holiday, tax-saving, removal of tariff) have also been used as pricing techniques to attract foreign investors in to Nigeria. Apart from the above, other policy measures include the liberalization of the economy (openness) competition policy repatriation of capital and income and other policies that ensure macroeconomic stability. All these policies are geared toward providing profitable opportunities for foreign investors to come and invest in the country's economy.

\section{METHODOLOGY}

The data used in this study are annual time series data spanning 1986 through 2005. The variables under consideration are foreign direct investment, exchange rate, liberalization and capital repatriation. Data on these variables were obtained from publications of the Central Bank of Nigeria. A major limitation of this study is that, the data, used is to some extent defective. But 


\section{Journal Of Agriculture and Social Research (JASR) Vol. 8, No.1, 2008}

despite this limitation, the study is able to achieve its objective. The econometrics approach was adopted in this study. Our null hypothesis of no significant relationship between foreign direct investment policy measures and the inflow of foreign direct investment was stated and tested using the ordinary least square regression technique. Our computing device was the Statistical Package for Social Sciences (SPSS). The R square $\left(\mathrm{R}^{2}\right)$ statistic (coefficient of determination) was used to test the power of the explanatory variables while the $\mathrm{t}$ - test and the F- ratio were used to test the significant of the policy measures in relation to foreign direct investment at 95 percent confidence interval.

\section{Model Specification}

The model for this study is given below.

$$
\text { FDI }=a_{o}+a_{1} L_{+} a_{2} E_{\text {Exh }}+a_{3} \text { CR }+ \text { U...... (1) Where }
$$

The a priori expectation sign for the variable ( $\mathrm{Lb}$, Exch and CR) is a positive $(+)$ sign. This implies that liberalization (openness), exchange rate and capital repatriation policies help to attract foreign direct investment into the country or that there is a direct relationship between the variables ( $\mathrm{Lb}$, Exch and CR) and foreign direct investment (FDI).

In the model:

FDI is foreign direct investment inflow.

$\mathrm{Lb}$ is liberalization (Non-oil export and Non oil import)

Exch is exchange rate

$\mathrm{CR}$ is capital repatriation

$\mathrm{U}$ is random term

$\mathrm{a}_{1}, \mathrm{a}_{2}$, and $\mathrm{a}_{3}$, are coefficients of policy variables.

$\mathrm{a}_{0}$ is the regression constant.

Equation (1) above can be logged because, the log-linear form permits a direct estimation and also improves the validity of the estimate and conclusions based on them (Amadi, 2002).

Therefore the log- linear equation takes the following form

In FDI $=a_{0}+a_{1}$ In Lb $+a_{2}$ In Exch $+a_{3}$ In CR + U..... (2)

Note volume of non oil export and non oil import are used as proxy to measure liberalization (openness).

The out flow of FDI is used as proxy for capital repatriation. 
Journal Of Agriculture and Social Research (JASR) Vol. 8, No.1, 2008

\section{Data Analysis}

Our null hypothesis, of no significant relationship between foreign direct investment policy measures and the inflow of foreign direct investment was tested using the ordinary least square regression method as stated earlier. 
The estimated regression equation is stated as follows.

In FDI=-1115.9331-288.373In Exch + 2.980E.02In LB+2.489In CR)
$(-0.19)(-2.360)$
(3.187)

$\mathrm{F}^{*}$ calculated $=5.330, \mathrm{df}=16$

Note:- The figures in parenthesis are $t$ values.

$\mathrm{R}^{2}(\mathrm{R}$ square $)=0.500$

From the results of the multiple regression in Appendix (A-E) $R^{2}$ (R square) is 0.50 . This shows that about 50 percent of the variation in the dependent variable (FDI) is caused by foreign direct investment policy measures, the remaining 50 percent may be attributed to variables not included in the model specified. They may include competitive nature of the environment, legal framework (Intellectual and property protection), and political stability.

The testing of the null hypothesis shows that there is a significant relationship between the foreign direct investment policy measures adopted in Nigeria and the inflow of foreign direct investment. This implies that the null hypothesis is rejected and alternative hypothesis accepted. This is because $\mathrm{F}$ calculated is greater than the critical value of $\mathrm{F}^{*}(3.10)$. The coefficient of the independent variables was tested for statistical significant at 5 percent significant level. The coefficient of exchange rate, liberalization and capital repatriation was found to be statistically significant (i.e., have direct relationship with FDI).

\section{CONCLUSION}

In the study we set out to determine the effectiveness of foreign direct investment policy measures in attracting foreign direct investment using the ordinary least square regression analysis to test the null hypothesis of no significant relationship between foreign direct investment policy measures and inflow of foreign direct investment. From the regression analysis and test of significant results we discovered that there is a positive and significant relationship between inflow of foreign direct investment, and liberalization and capital repatriation. But there is a negative relationship between exchange rate and inflow of foreign direct investment, although its coefficient is statistically significant.

The multiple regression result (Appendix A-E) shows that foreign direct investment policy measures explained about 50 percent of the variation in foreign direct investment. The null hypothesis was rejected, confirming that there is a significant relationship between the policy variables and the inflow of foreign direct investment.

\section{REFERENCES}

Aremu M.C. (2003) Foreign Direct Investment Policies, in Naanna O.J, Alade, S.O and Odoko, F. $\mathrm{O}$ (eds) Nigerian $\quad$ Foreign Direct Investment. Central Bank of Nigeria Abuja.

Central Bank of Nigeria (1997) Foreign Investment and Macro economic stability in Nigeria. Abuja: Central Bank Publication.

Dunning. J. (1987) Grade, Location of Economic and the MNE; A search for an Edectic Approach', in Ohlin et al (eds).

Fernandex. A. and Maritiel .V. (1996) "Attracting Foreign Manufacturing: Investment Promotion and Agglomeration”. Regional Science and urban Economic 29 (2): 197- 218. 
Green.A. and Villian. V (1991) “Foreign Direct Investment and Efficiency benefits: A Conditional Quantile Analysis” Oxford Economic Papers 54: 449 - 69.

Mankiw (1997) “Foreign Direct Investment as a catalyst for Industrial Development” European Economic Review 43 (2):335-56.

Obadan. M. I and Odusola A F (2001) “The impact of savings ～on Economic growth". NCE MA Journal of Economic management Vol 3 No. 1.

Pfefferman .C. and Madarassy (1992) “Determinants of Foreign Direct Investment” Trinity Economic Papers 02/06 Trinity College, Dublin.

Shaikh .M. (1999) "Foreign Direct Investment and Technology Transfer. Economic and Financial Review Volume 31, No. 2, June 1999.

Ukeje. E.U. (2003) A Survey of Economic and Social Condition in Nigeria Central Bank of Nigeria Bullion Vol. 15. 
Journal Of Agriculture and Social Research (JASR) Vol. 8, No.1, 2008

\section{APPENDIX A}

Data series of FDI, Exchange Rates, Liberalization and Capital Repatriation 1986-2005

\begin{tabular}{|l|l|l|l|l|l|}
\hline & Year & Fdi & exch & lb & cr \\
\hline 1 & 1986 & 4024.0 & 2.0206 & 5621.8 & 1524.40 \\
\hline 2 & 1987 & 5110.8 & 4.0179 & 17843.6 & 4430.80 \\
\hline 3 & 1988 & 6236.7 & 4.5367 & 20400.0 & 4891.10 \\
\hline 4 & 1989 & 4692.7 & 7.3916 & 29143.0 & 5132.11 \\
\hline 5 & 1990 & 10450.2 & 8.0378 & 42904.4 & 10914.50 \\
\hline 6 & 1991 & 5610.2 & 9.9095 & 86393.3 & 3802.20 \\
\hline 7 & 1992 & 11730.7 & 17.2984 & 127817.5 & 3461.50 \\
\hline 8 & 1993 & 42624.9 & 22.0511 & 129484.6 & 9630.50 \\
\hline 9 & 1994 & 7825.5 & 21.8861 & 125788.2 & 3918.30 \\
\hline 10 & 1995 & 55999.3 & 21.8861 & 622397.9 & 7322.30 \\
\hline 11 & 1996 & 5672.9 & 21.8861 & 423775.4 & 2941.90 \\
\hline 12 & 1997 & 10004.0 & 21.8861 & 707977.4 & 4273.00 \\
\hline 13 & 1998 & 32434.5 & 21.8861 & 695634.7 & 8355.60 \\
\hline 14 & 1999 & 4035.5 & 92.6934 & 670046.8 & 2256.40 \\
\hline 15 & 2000 & 16453.6 & 102.1052 & 7890.27 & 13106.60 \\
\hline 16 & 2001 & 4937.0 & 111.9433 & 1149082 & 1560.00 \\
\hline 17 & 2002 & 8988.5 & 120.9702 & 1458912 & 781.70 \\
\hline 18 & 2003 & 13531.2 & 129.3565 & 1810782 & 475.10 \\
\hline 19 & 2004 & 20064.4 & 133.5004 & 1900670 & 155.70 \\
\hline 20 & 2005 & 26083.7 & 131.6619 & 2184914 & 202.40 \\
\hline
\end{tabular}

Source: CBN Annual Bulletin 2006

\section{APPENDIX B}

\section{Coefficients $^{\text {a }}$}

\begin{tabular}{|l|l|l|l|l|l|}
\hline \multirow{2}{*}{ Model } & \multicolumn{2}{|l|}{ Correlations } & \multicolumn{2}{l|}{ Collinearity Statistics } \\
\cline { 2 - 6 } & Zero-order & Partial & Part & Tolerance & VIF \\
\hline 1 (Constant) & & & & & \\
EXCH & .032 & -.508 & -.417 & .158 & 6.318 \\
LB & .198 & .623 & .563 & .147 & 6.807 \\
CR & .375 & .625 & .566 & .766 & 1.366 \\
& & & & & \\
\hline
\end{tabular}

a.

Dependent Variable: FDI

\section{Coefficient Correlations ${ }^{\text {a }}$}

\begin{tabular}{|l|l|l|l|}
\hline Model & CR & EXCH & LB \\
\hline
\end{tabular}


Journal Of Agriculture and Social Research (JASR) Vol. 8, No.1, 2008

\begin{tabular}{|c|c|c|c|c|c|}
\hline 1 & Correlations & $\begin{array}{l}\text { CR } \\
\text { EXCH } \\
\text { LB }\end{array}$ & $\begin{array}{l}1.000 \\
-.077 \\
.278\end{array}$ & $\begin{array}{l}-.077 \\
1.000 \\
-.900\end{array}$ & $\begin{array}{r}.278 \\
-.900 \\
1.000\end{array}$ \\
\hline & Covariances & $\begin{array}{l}\text { CR } \\
\text { EXCH } \\
\text { LB }\end{array}$ & $\begin{array}{r}.605 \\
-7.327 \\
2.022 \mathrm{E}-03\end{array}$ & $\begin{array}{r}-7.327 \\
14933.037 \\
-1.028\end{array}$ & $\begin{array}{r}2.022 \mathrm{E}-03 \\
\mathrm{I} .028 \\
8.744 \mathrm{E}-05\end{array}$ \\
\hline
\end{tabular}

a. Dependent Variable: FDI

Collinearity Diagnostics ${ }^{\text {a }}$

\begin{tabular}{|c|c|c|c|c|c|c|c|}
\hline \multirow[b]{2}{*}{ Model } & \multirow[b]{2}{*}{ Dimension } & \multirow[b]{2}{*}{ Eigen value } & \multirow[b]{2}{*}{$\begin{array}{l}\text { Condition } \\
\text { Index }\end{array}$} & \multicolumn{4}{|c|}{ Variance Proportions } \\
\hline & & & & (Constants) & $\mathrm{EXCH}$ & LB & CR \\
\hline \multirow{4}{*}{2} & 1 & 2.937 & 1.000 & .02 & .01 & .01 & .02 \\
\hline & & .905 & 1.801 & .02 & .01 & .02 & .18 \\
\hline & 3 & .117 & 5.015 & .94 & .05 & .01 & .74 \\
\hline & 4 & 4.076E-02 & 8.489 & .03 & .92 & .97 & .06 \\
\hline
\end{tabular}

a.

Dependent Variable: FDI

\section{Residual Statistics ${ }^{\text {a }}$}

\begin{tabular}{|l|r|r|r|r|c|}
\hline & & & \multicolumn{1}{l|}{ Std. } & \\
& Minimum & Maximum & Mean & Deviation & $\mathrm{N}$ \\
\hline Predicted value & -2264.057 & 34099.301 & 14825.515 & 10053.8311 & 20 \\
Residual & -14562.566 & 26654.324 & .000 & 10056.6796 & 20 \\
Std. Predicted value & -1.917 & 1.917 & .000 & 1.000 & 20 \\
Std. Residual & -1.329 & 2.432 & .000 & .918 & 20 \\
& & & & & \\
\hline
\end{tabular}

a. Dependent Variable: FDI 
Journal Of Agriculture and Social Research (JASR) Vol. 8, No.1, 2008

\section{APPENDIX C}

\section{ANOVA $^{\text {b }}$}

\begin{tabular}{|c|c|c|c|c|c|}
\hline Model & $\begin{array}{l}\text { Sum of } \\
\text { squares }\end{array}$ & $\mathrm{df}$ & Mean square & $\mathrm{F}$ & Sig. \\
\hline $\begin{array}{ll}1 & \text { Regression } \\
& \text { Residual } \\
& \text { Total }\end{array}$ & $\begin{array}{l}1.92 \mathrm{E}+09 \\
1.92 \mathrm{E}+09 \\
3.84 \mathrm{E}+09\end{array}$ & $\begin{array}{r}3 \\
16 \\
19\end{array}$ & $\begin{array}{l}640170286.11 \\
120099955.82\end{array}$ & 5.330 & $.010^{\mathrm{a}}$ \\
\hline
\end{tabular}

a. Predictors: (constant), CR,EXCH,LB

b. Dependent variable: FDI

\section{Coefficient $^{\text {a }}$}

\begin{tabular}{|c|c|c|c|c|c|}
\hline \multirow[t]{2}{*}{ Model } & \multicolumn{2}{|c|}{$\begin{array}{l}\text { Unstandardized } \\
\text { Coefficients }\end{array}$} & \multirow{2}{*}{$\begin{array}{l}\begin{array}{l}\text { Standardized } \\
\text { Coefficients }\end{array} \\
\text { Beta }\end{array}$} & \multirow[t]{2}{*}{$\mathrm{t}$} & \multirow[t]{2}{*}{ Sig. } \\
\hline & B & Std. Error & & & \\
\hline $\begin{array}{ll}1 \text { (Constant) } \\
\text { EXCH } \\
\text { LB } \\
\text { CR }\end{array}$ & $\begin{array}{r}-1115.933 \\
-288.373 \\
2.980 \mathrm{E}-02 \\
2.489\end{array}$ & $\begin{array}{r}5827.896 \\
122.201 \\
.009 \\
.778\end{array}$ & $\begin{array}{r}-1.049 \\
1.470 \\
.646\end{array}$ & $\begin{array}{r}-.191 \\
-2.360 \\
3.187 \\
3.200\end{array}$ & $\begin{array}{l}.851 \\
.031 \\
.006 \\
.006\end{array}$ \\
\hline
\end{tabular}

\section{APPENDIX D}

Coefficient $^{\text {a }}$

\begin{tabular}{|cc|c|c|}
\hline \multirow{2}{*}{ Model } & \multicolumn{2}{|c|}{$95 \%$ Confidence Interval for B } \\
\cline { 3 - 4 } EXCH & (Constant) & -13470.521 & Upper Bound \\
\hline \multirow{2}{*}{ LB } & -547.427 & 11238.654 \\
\multicolumn{2}{|c|}{ LR } & .010 & -29.319 \\
CR & .840 & .050 \\
\hline
\end{tabular}


Journal Of Agriculture and Social Research (JASR) Vol. 8, No.1, 2008

\section{APPENDIX E}

\section{Regression}

\section{Descriptive Statistics}

\begin{tabular}{|l|l|r|l|}
\hline & Mean & Std. Deviation & N \\
\hline FDI & 14825.515 & 14220.2786 & 20 \\
EXCH & 50.346250 & 51.7162245 & 20 \\
LB & 649930.78 & 701480.2395 & 20 \\
CR & 4456.8055 & 3693.34276 & 20 \\
\hline
\end{tabular}

\section{Correlations}

\begin{tabular}{|ll|r|r|r|r|}
\hline & & FDI & EXCH & LB & CR \\
\hline Pearson Correlation & FDI & 1.000 & .032 & .198 & .375 \\
& EXCH & .032 & 1.000 & .917 & -.412 \\
& LB & .198 & .917 & 1.000 & -.479 \\
& CR & .375 & -.412 & -.479 & 1.000 \\
\hline Sig. (1-tailed) & FDI &. & .446 & .201 & .052 \\
& EXCH & .446 &. & .000 & .035 \\
& LB & .201 & .000 &. & .016 \\
& CR & .052 & .035 & .016 &. \\
\hline $\mathrm{N}$ & FDI & 20 & 20 & 20 & 20 \\
& EXCH & 20 & 20 & 20 & 20 \\
& LB & 20 & 20 & 20 & 20 \\
& CR & 20 & 20 & 20 & 20 \\
\hline
\end{tabular}

\section{Variables Entered/Removed ${ }^{\text {b }}$}

\begin{tabular}{|l|l|l|l|}
\hline Model & Variable Entered & Variables Removed & Method \\
\hline 1 & $\begin{array}{l}\mathrm{CR}_{\mathrm{a}} \mathrm{EXCH}, \\
\mathrm{LB}\end{array}$ & & Enter \\
\hline
\end{tabular}

a. All requested variables entered

b. Dependent Variable: FDI

\section{Model Summary ${ }^{b}$}

\begin{tabular}{|l|l|c|l|l|}
\hline Model & $\mathrm{R}$ & R Square & $\begin{array}{l}\text { Adjusted R } \\
\text { Square }\end{array}$ & $\begin{array}{l}\text { Std. Error } \\
\text { the Estimate }\end{array}$ \\
\hline 1 & $.707^{\mathrm{a}}$ & .500 & .406 & 10959.0125 \\
\hline
\end{tabular}

\section{Model Summary}

\begin{tabular}{|l|l|l|l|l|}
\hline \multirow{3}{*}{ Model } & \multicolumn{3}{|c|}{ Change Statistics } & \\
\cline { 2 - 6 } & R Square & & & \\
\hline
\end{tabular}


Journal Of Agriculture and Social Research (JASR) Vol. 8, No.1, 2008

\begin{tabular}{|l|l|l|l|l|l|l|}
\hline & Change & F Change & df1 & df2 & $\begin{array}{l}\text { Sig. F. F } \\
\text { Change }\end{array}$ & $\begin{array}{l}\text { Durbin- } \\
\text { Watson }\end{array}$ \\
\hline 1 & .500 & 5.330 & 3 & 16 & .010 & 1.784 \\
\hline
\end{tabular}

a. Predictors: (Constant), CR, EXCH, LB

b. Dependent Variable: FDI 